REVIEW ARTICLE

\title{
What do anti-collagen antibodies mean?
}

\author{
K Morgan
}

The main structural proteins of the connective tissues in the body are collagens, of which at least 12 genetically distinct types have so far been described. The types of collagen found in a specific tissue are related to the function of that tissue and they have specific distributions within individual tissues.

In general the basic structure of all native collagens consists of three polypeptide $\alpha$ chains in the form of a triple helical domain(s) with repeating glycine-X-Y triplets where $X$ is often proline and $\mathrm{Y}$ is often hydroxyproline. ${ }^{1}$ Denaturation of collagen molecules leads to unfolding of the triple helix disclosing the linear sequence of amino acids along the length of the individual $\alpha$ chains. Collagen molecules have antigenic sites (epitopes) owing to the three dimensional structure of the molecule, and these epitopes are lost upon disruption of this conformation. They also have determinants owing to the linear arrangement of the amino acids in each $\alpha$ chain and in the non-helical extension peptides. Extraction procedures used to isolate and purify many of the collagens, particularly those in articular cartilage, result in the loss of the non-helical extension peptides. Thus investigations of immunity to collagens are often restricted to epitopes found in the helical region of the molecules in their native or denatured state.

Antibodies to native and denatured collagens, in particular to type I and II collagens, have been reported in a number of diseases, including ankylosing spondylitis, emphysema, gout, juvenile chronic arthritis, lepromatous leprosy, osteoarthritis, osteoporosis, Paget's disease, psoriatic arthritis, relapsing polychondritis, rheumatoid arthritis (RA), scleroderma, systemic lupus erythematosus, and traumatic synovitis. $^{2-17}$ Many of the early reports used haemagglutination assays where other serum components such as fibronectin might have caused anomalously high rates of detection. ${ }^{18}$ Most of the 12 types of collagen were unknown when the earlier studies were conducted and some of the collagens used might have been contaminated with these more recently discovered collagens. Only small numbers of patients have been studied in some reports, and there have been varying definitions of normal ranges in healthy controls. Thus it has been difficult to reconcile many of the published findings of the presence and the incidence of antibodies to different collagens in different diseases. For example, incidences between 3\% and $71 \%$ have been described for the presence of antibodies to native type II collagen in patients with RA.

There are now improved techniques for the purification of collagens and improved solid phase radioimmunoassays or enzyme linked immunosorbent assays (ELISA) for antibodies to collagens. Using these techniques we can at least draw conclusions about antibodies to collagens in patients with RA where there is an inflammatory response with destruction of articular cartilage in synovial joints.

The tissues of synovial joints contain many of the 12 types of collagen. Articular cartilage in mature joints contains at least four types of collagen. ${ }^{19}$ The major collagen quantitatively is type II, with the other three quantitatively minor collagens being types VI, IX, and XI. The surrounding tissues of the joint contain types I, III, and V collagen, with type I collagen, for example, occurring in bone and in synovium.

If one looks at a large group of patients with established RA and compares them with a large group of normal, healthy controls then the incidence of antibodies to native type II collagen for the patients with RA is in the region of $10 \%$ with antibodies to denatured type II collagen occurring in about $25 \% .^{15}$ The antibodies are mainly of the IgG class, though IgM and IgA antibodies to collagens occur in some patients in association with the IgG antibodies (personal observations). IgG1 and IgG3 are the predominant subclasses of this IgG for both native and denatured type II collagen. ${ }^{20}{ }^{21}$ Both these subclasses are potent fixers of complement.

Antibodies to other native collagens present in the joint occur less often (in 2-3\% of patients with RA), while antibodies to denatured type I and denatured type XI collagen occur in about $15 \% .{ }^{15}$ Antibodies to these other native collagens are generally found in those patients who also have antibodies to native type II collagen, but antibodies to denatured collagens are more widespread. Antibodies to type II collagen may occur more commonly very early in the disease and later disappear in most patients, ${ }^{22}$ but this has yet to be confirmed by other workers. The other types of collagen have not yet been examined in this way.

No direct correlation between the presence of antibodies to type II collagen and measurements of disease activity have been found when single time points in the course of disease in patients have been examined. ${ }^{23}{ }^{24}$ Longitudinal studies
Manchester, Department of Rheumatology, Stopford Building Oxford Road Manchester M13 9PT K Morgan 
have shown an association, however, between these antibodies and disease activity in some patients, at least for some times in their disease. $^{25}$ Those studies ${ }^{25}$ also emphasised that antibodies to cartilage collagens can be present even after disease of long duration, that the response to individual collagens seems to be selective, that the antibodies are not a static or uniform population, and that antibodies to native and denatured type II collagen may be associated with severe disease.

There is evidence that patients with RA who have antibodies to native type II collagen in established disease are a genetic subset of patients with RA. A higher incidence of the HLA phenotype HLA-DR3 or HLA-DR7, or both, was seen in patients with RA and with antibodies to native type II collagen in studies by one group 242627 and an association with the HLA-DR2 phenotype by another group. ${ }^{28}$ These and other studies ${ }^{29}{ }^{30}$ have all confirmed a lack of association between the HLA-DR4 phenotype and antibodies to native type II collagen, but an association between antibodies to denatured type II collagen and HLA-DR4 has been shown. ${ }^{31}$ No large studies have been made relating the presence of antibodies to other collagens with the genetic phenotype of patients.

Collagens are large and complex molecules and contain many different epitopes. Thus values obtained from the measurement of antibodies to whole collagen molecules are the sum of a number of antibodies to different epitopes on the molecules. The number of such antibodies may vary in the same patient at different times and also between patients. Some epitopes may be shared by more than one type of collagen, whereas others will be unique. One explanation for the occurrence of antibodies to a variety of types of collagen could be that cross reactive antibodies binding to common epitopes on the different collagen molecules are formed. This may particularly occur in the case of antibodies to denatured type II and type XI collagen as the $\alpha$ l(II) chain of type II collagen is biochemically similar to the $\alpha 3(\mathrm{XI})$ chain of type XI collagen but not to the $\alpha \mathrm{l}(\mathrm{XI})$ or $\alpha 2(\mathrm{XI})$ chains. ${ }^{32}$ Thus antibodies detected to denatured type XI collagen may only be antibodies raised to type II collagen that also bind to type XI collagen and type XI collagen itself may not be immunogenic. This is certainly not the case in all patients with antibodies to denatured type XI collagen as immunoblotting techniques have shown that antibodies binding to the $\alpha 1(\mathrm{XI})$ and $\alpha 2(\mathrm{XI})$ chains of type XI collagen are present. ${ }^{33}$

Collagen molecules can be split into smaller fragments (CB-peptides) by cyanogen bromide. Similar immunoblotting studies on these cyanogen bromide derived peptides of type II collagen using serum samples from patients with RA have shown that there was not a uniform response to all the peptides in all patients. This finding again shows that the immune response to collagens is selective in these patients. Antibodies to the CB-8 or CB-11 peptides, however, were the most common antibodies found in these patients. Studies on sequential samples from individual patients showed changes not only in the number of peptides to which antibodies bound but also in the titre of antibody to individual peptides (personal observations).

Thus we can conclude that antibodies to a variety of native and denatured collagens occur in a proportion of patients with RA who have established disease, that antibodies to denatured collagens are more widespread than antibodies to native collagens, and that antibodies to denatured type II collagen are the most common. Antibodies to native type II collagen may be restricted to a genetic subset of patients and be associated with severe disease in some patients. Antibodies to different epitopes if they are involved in the pathogenesis may be more important than others at different stages of the disease.

What, if any, is the role of these antibodies in the initiation and perpetuation of rheumatoid arthritis?

It is possible that all patients with RA (or only a genetic subset) develop an immune response to a foreign antigen which shares some epitopes present on type II collagen or another cartilage collagen. The immune response may produce antibodies not only to the foreign determinants on the antigen but also to the shared epitopes owing to the production of $\mathrm{T}$ helper cells, which give help to B cells specific for foreign determinants and to B cells specific for cross reacting determinants. Thus the resultant immune response could initiate joint inflammation by the binding of antibodies to epitopes on the collagen in the cartilage. From human studies we do not have enough evidence to determine whether antibodies to collagens cause RA in all, or any, patients. IgG from a patient with RA without rheumatoid factor, but with high levels of anti-type II collagen antibodies, has been shown to induce a synovitis when given intravenously to mice. ${ }^{34}$

Studies of immunity to collagens in animals provide us with some evidence that antibodies to collagens are capable of inducing an inflammatory arthritis. Immunisation of rats or mice with type II collagen induces an inflammatory polyarthritis ${ }^{35-40}$ with some features that resemble rheumatoid arthritis. ${ }^{41}$ The induction of arthritis is associated with the immune response to the immunising collagen, particularly with the development of antibodies to collagens. ${ }^{42-47}$ Immunisation of rats and mice with type XI collagen induces a similar arthritis (personal observations), ${ }^{48}$ and antibodies raised in the rat to type II collagen cross react with type XI collagen and vice versa. ${ }^{33} 48$ More recently, a similar arthritis has been produced in monkeys. ${ }^{49} 50$ In most instances the arthritis is produced by immunising the animal with a foreign type II collagen. It is important that the antibodies produced are complement fixing, $51-54$ cross react with the animal's own collagen,, 51 ' 55 and bind to cartilage in the joints. ${ }^{45} 46$

Evidence has been presented that the immune response to type II collagen in animals is under genetic control (for review see ref 57), paralleling the human studies. There is evidence to suggest that antibodies only to certain parts of 
the type II collagen molecule may be important in arthritis induction. ${ }^{33} 5859$ Thus in patients with RA there may be pathogenic and nonpathogenic antibodies.

An alternative explanation for the presence of antibodies to collagens in RA is that they are only produced after the onset of arthritis caused by some other mechanism. The collagens in the cartilage are held in an immunologically privileged site and thus there is normally no response to them. With breakdown of the cartilage in RA, the collagens are exposed to the cells of the immune system and an immune response develops to them in all (or only in a genetic subset) of the patients with RA. The antibodies produced would thus be secondary to the initiation of arthritis but might play a part in perpetuation of the disease. Antibodies to type II collagen in patients with RA are predominantly of the complement fixing subclasses IgGl and IgG3, ${ }^{20} 21$ are present in synovial fluids, ${ }^{60}$ are synthesised by cells in the synovium, ${ }^{5}$ and bind to cartilage. ${ }^{23}$ Thus they have all the requirements to fulfil this role. Antibodies to the other cartilage collagens have not been so extensively studied but they too could be involved.

A third possibility is that the antibodies to collagens are not formed as a result of antigenic stimulation but are the result of polyclonal B cell activation or immune disregulation. The selective nature of the response seen to different collagens in sequential studies ${ }^{25}$ argues against this possibility. It has also been argued that as antibodies to collagens may occur without apparent joint disease then they must be irrelevant to RA. This argument does not take into account, however, the fact that antibodies to collagens alone may not be sufficient to produce joint involvement and that other factors may also be important. Neither does it recognise that the antibodies to type II collagen, for example, may be to a different combination of epitopes in different diseases and that antibodies to only a few epitopes may be important in joint involvement.

Whether or not antibodies to collagens are involved in the pathogenesis of RA, they may be useful as markers of cartilage destruction in some patients. Changes in serum antibodies to collagens in individual patients may provide an early indication of renewed cartilage destruction, in previously affected joints or in newly affected joints, before it is clinically evident, thus allowing earlier appropriate treatment.

In conclusion, we do not know exactly what the presence of antibodies to collagens in patients means, and their routine measurement even in patients with RA will not, at present, aid disease management. Autoimmunity to collagens in patients with RA is a complex process and obviously if antibodies to collagens are involved in joint inflammation they are not the only mechanism involved in joint destruction. From animal studies we can deduce possible mechanisms for the role of these antibodies in either the production or perpetuation of arthritis and investigate other mechanisms which may be involved.

Further investigation of antibodies to col- lagens, particularly at the level of antibodies to individual epitopes, both in animals and in patients with RA or other diseases, will help us to understand which antibodies may be important in disease processes. We may also determine which antibodies may be useful markers of disease activity and therefore useful in the monitoring of drug treatment.

We should eventually understand how these antibodies interact with other mechanisms such as $T$ cell responses to collagens and how we can manipulate the immune response to collagens. ${ }^{61-63}$ It is important to determine whether such manipulation can change the course of disease progression and thus possibly be a novel form of treatment, at least in a subset of patients where conventional treatments are not successful.

I believe that the study of immunity to collagens will be an interesting and important area of research over the next decade and that we will be able to answer the question 'what do anti-collagen antibodies mean?'.

1 Weiss J B. Collagens and collagenolytic enzymes. In: Hukin D W L, ed. Connective tissue matrix. London: Macmillan, 1984: 17-55.

2 Steffen C, Timpl R. Antigenicity of collagen and its application in the serological investigation of rheumatoid arthritis sera. Int Arch Allergy Appl Immunol 1963; 22: 333-49.

3 Michaeli D, Fudenberg $\mathrm{H} \mathrm{H}$. The incidence and antigenic specificity of antibodies directed against denatured human collagen in rheumatoid arthritis. Clin Immunol Immunopatho collagen in rheumat $1974 ; 2$ : 153-9.

4 Cracchiolo A, Michaeli D, Goldberg L S, Fudenberg H H. The occurrence of antibodies to collagen in synovial fluids. Clin Immunol Immunopathol 1975; 3: 567-74.

5 Mestecky J, Miller E J. Presence of antibodies specific to cartilage-type collagen in rheumatoid synovial tissue. Clin Exp Immunol 1975; 22: 453-6.

6 Andriopoulos N A, Mestecky J, Miller E J, Bradley E L. Antibodies to native and denatured collagens in sera of patients with rheumatoid arthritis. Arthritis Rheum 1976; 19: 613-7.

7 Menzel J, Steffen C, Kolarz G, Eberl R, Frank O, Thumb N. Demonstration of antibodies to collagen and of anti-collagen immune complexes in rheumatoid arthritis synovial fluids. Ann Rheum Dis 1976; 35: 446-50.

8 Foidart J M, Abe S, Martin G R, et al. Antibodies to type II collagen in relapsing polychondritis. $N$ Engl $\mathcal{J}$ Med 1978 299: 1203-7.

9 McAdam K, Fudenberg H, Michaeli P. Antibodies to collagen in patients with leprosy. Clin Immunol Immunopathol 1978; 9: 16-19.

10 Greenbury C L, Skingle J. Anti-cartilage antibody. 7 Clin Pathol 1979; 32: 826-31.

11 Ebringer R, Rook G, Swana G T, Bottazzo G F, Doniach D. Antibodies to cartilage and type II collagen in relapsing polychondritis and other rheumatic diseases. Ann Rheum Dis 1981; 40: 473-9.

12 Clague R B, Shaw M J, Holt P J L. Incidence and correlation between serum IgG and IgM antibodies to native type II collagen in patients with chronic inflammatory arthritis. Ann Rheum Dis 1981; 40: 6-10.

13 Trentham D E, Kammer G M, McCune W J, David J R. Autoimmunity to collagen: a shared feature of psoriatic and
rheumatoid arthritis. Arthritis Rheum 1981;24: 1363-9.

rheumatoid arthritis. Arthritis Rheum 1981; 24: 1363-9.
Stuart J M, Huffstutter E H, Townes A S, Kang A H Incidence and specificity of antibodies to type I, II, III, IV and $\mathrm{V}$ collagen in rheumatoid arthritis and other rheumatic diseases as measured by ${ }^{125} \mathrm{I}$-radioimmunoassay. Arthritis Rheum 1983; 26: 832-40

15 Morgan K, Clague R B, Collins I, Ayad S, Phinn S D, Holt P $J$ L. Incidence of antibodies to native and denatured cartilage collagens (types II, IX and XI) and to type I collagen in rheumatoid arthritis. Ann Rheum Dis 1987; 46: $902-7$.

16 Choi E K, Gatenby P A, McGill N W, Bateman J F, Cole W G, York J R. Autoantibodies to type II collagen: occurrence in rheumatoid arthritis, other arthritides, autoimmune connective tissue diseases and chronic inflam

17 Charriere G, Hartmann D J, Vignon E, Ronziere M, Herbage D, Ville G. Antibodies to types I, II, IX and XI collagen in D, Ville G. Antibodies to types I, II, IX and XI collagen in the serum of patients with

18 Beard J K, Lea D J, Ryvar R. Anomalous reactions in the haemagglutination assay for anti-collagen antibodies: haemagglutination assay for anti-collagen antibodies: studies on patients with rheumatoid or ch

19 Grant M E, Ayad S, Kwan A P L, Bates G P, Thomas J T, 
McClure J. The structure and synthesis of cartilage collagens. In: Glauert A M ed The control of tissue damage. Amsterdam: Elsevier, 1988: 3-28.

20 Watson W C, Cremer M A, Wooley P H, et al. Assessment of the potential pathogenicity of type II collagen autoantibodies in potential pathogenicity of type II collagen autoantibodies 29: $1316-21$.

21 Collins I, Morgan K, Clague R B, Brenchley P E C, Holt P J L. IgG subclass distribution of anti-native type II collagen and anti-denatured type II collagen antibodies in patients with rheumatoid arthritis. F Rheumatol 1988; 15: 770-4.

22 Pereira R S, Black C M, Duance V C, Jones V E, Jacoby R K, Welsh K I. Disappearing collagen antibodies in rheumatoid arthritis. Lancet 1985; ii: 501-2.

23 Clague R B, Firth S A, Holt P J L, Skingle J, Greenbury C L, Webley $M$. Serum antibodies to type II collagen in rheumatoid arthritis: comparison of six immunological methods and clinical features. Ann Rheum Dis 1983; 42: methods

24 Klimiuk P S, Clague R B, Grennan D M, Dyer P A, Smeaton I, Harris $R$. Autoimmunity to native type II collagen-a I, Harris $R$. Autoimmunity to native type II collagen-a distinct genetic subs

25 Morgan K, Clague R B, Collins I, Ayad S, Phinn S D, Holt P $J$ L. A longitudinal study of anti-collagen antibodies in patients with rheumatoid arthritis. Arthritis Rheum 1989; 32: $139-45$.

26 Dyer P A, Clague R B, Klouda P T, Firth S A, Harris R, Holt $P$ J L. HLA antigens in patients with rheumatoid arthritis and antibodies to native type II collagen. Tissue Antigens 1982; 20: 394-6.

27 Sanders P A, Grennan D M, Klimiuk P S, et al. Gm allotypes and HLA in rheumatoid arthritis patients with circulating antibodies to native type II collagen. Ann Rheum Dis 1987; 46: $391-4$.

28 Wooley P H, Luthra H S, O'Duffy J D, Bunch T W, Moore $\mathrm{S} B$, Stuart J M. Anti-type II collagen antibodies in rheumatoid arthritis. The influence of HLA phenotype. Tissue Antigens 1984; 23: 263-9.

29 Kammer G M, Trentham D E. HLA-DR4 is not a requisite for autoimmunity to collagen in rheumatoid arthritis. Arthritis Rheum 1984; 27: 489-95.

30 Collier D H, Kerwar S S, Garovoy M R, Fye K H, Stobo J D. Anticollagen antibodies and immune response gene products
in rheumatoid arthritis. Arthritis Rheum 1984; 27: 1201-9.

31 Rowley M, Tait B, Mackay I R, Cunningham T, Phillips B. Collagen antibodies in rheumatoid arthritis: significance of Collagen antibodies in rheumatoid arthritis: significance of antibodies to denatured collagen and their associ

32 Burgeson R E, Hollister D W. Collagen heterogenicity in human cartilage: identification of several new collagen chains. Biochemi Biophys Res Commun 1979; 87: 1124-31.

33 Morgan K, Buckee C, Collins I, Ayad S, Clague R B, Holt P J L. Antibodies to type II and XI collagens: evidence for the formation of antigen specific as well as cross reacting antibodies in patients with rheumatoid arthritis. Ann Rheum Dis 1988; 47: 1008-13.

34 Wooley P H, Luthra H S, Singh S K, Huse A R, Stuart J M, David C S. Passive transfer of arthritis to mice by injection of human anti-type II collagen study. Mayo Clin Proc 1984; 59: $737-43$.

35 Trentham D E, Townes A S, Kang A H. Autoimmunity to type II collagen: an experimental model of arthritis. $\mathcal{f}$ Exp

36 Stuart J M, Cremer M A, Kang A H, Townes A S. Collagen induced arthritis in rats: evaluation of early immunological events. Arthritis Rheum 1979; 22: 1344-51.

37 Morgan K, Clague R B, Shaw M J, Holt P J L. Native type II collagen-induced arthritis in the rat. I. Incidence and humoral response to collagen. Ann Rheum Dis 1980; 39: 285-90

38 Staines $\mathrm{N} A$, Hardingham $T$, Smith $M$, Henderson $B$. Collagen-induced arthritis in the rat: modification of immune and arthritic responses by free collagen and immune anticollagen antiserum. Immunology 1981; 44: 737-44.

39 Courtenay J S, Dallman M J, Dayan A D, Martin A, Mosedale B. Immunisation against heterologous type II collagen-induced arthritis in mice. Nature 1980; 282: 666-8.

40 Stuart J M, Townes A S, Kang A H. Nature and specificity of the immune response to collagen in type II collagen-induced arthritis in mice. $\mathcal{J}$ Clin Invest 1982; 69: 673-83.
41 Trentham D E. Collagen arthritis as a relevant model for theumatoid arthritis. Evidence pro and con. Arthritis Rheum 1982; 25: 911-6.

42 Clague R B, Morgan K, Shaw M J, Holt P J L. Native type II collagen-induced arthritis in the rat. II. Relationship between the humoral response to native type II collagen and arthritis. Rheumatol 1980; 7: 775-82.

43 Ofosu-Appiah W A, Morgan K, Holt P J L. Native type II collagen-induced arthritis in the rat. III. Relationship between the cellular immune response to native type collagen and arthritis. Ann Rheum Dis 1983; 42: 331-7.

44 Kerwar S S, Englert M E, McReynolds R A, et al. Type II collagen-induced arthritis. Studies with purified anti-collagen immunoglobulin. Arthritis Rheum 1983; 26: 1120-31.

45 Kerwar S S, Gordon S, McReynolds R A, Oronsky A L. Passive transfer of arthritis by purified anticollagen mmunoglobulin: localisation of ${ }^{125}$ I-labelled antibody. Clin Immunol Immunopathol 1983; 29: 318-22.

46 Stuart J M, Tomoda K, Yoo T J, Townes A S, Kang A H. Serum transfer of collagen-induced arthritis. II. Identification and localisation of auto-antibody to type II collagen in donor and recipient rats. Arthritis Rheum 1983; 26: 1237-44.

47 Ofosu-Appiah W A, Morgan K, Holt P J L. Native type II collagen-induced arthritis in the rat. Studies of the humoral response to collagen at the cellular level. $\mathcal{F}$ Rheumatol 1984; 11: $432-7$.

48 Morgan K, Evans H B, Firth S A, et al. $1 \alpha 2 \alpha 3 \alpha$ collagen is arthritogenic. Ann Rheum Dis 1983; 42: 680-3.

49 Cathcart E S, Haynes K C, Gonnerman W A, Lazzari A A, Franzblau C. Experimental arthritis in a non-human primate. 1: Induction by bovine type II colllagen. Lab Invest 1986; 54: $26-31$.

50 Stuart J M, Kang A H. Monkeying around with collagen autoimmunity and arthritis. Lab Invest 1986; 54: 1-3.

51 Morgan K, Clague R B, Shaw M J, Firth S A, Twose T M Holt P J L. Native type II collagen-induced arthtritis in the rat: the effect of complement depletion by cobra venom factor. Arthritis Rheum 1981; 24: 1356-62.

52 Kerwar S S, Bauman N, Oronsky A L, Slobcode A E. Studies on type II collagen-induced polyarthritis. Effect of complement depletion. F Immunopharmacol 1982; 3: 323-38.

53 Morgan K, Ofosu-Appiah W A, Holt P J L. Collageninduced arthritis - use of the direct and indirect haemolytic plaque assay to study the humoral response to collagen. Clin Exp Rheumatol 1985; 3: 229-36.

54 Firth S A, Morgan K, Evans H B, et al. IgG subclasses in a collagen-induced arthritis in the rat. Immunol Lett 1984; 7: 243-7.

55 Phinn S D, Morgan K, Holt P J L. Collagen-induced arthritis: antibody production by lymphocytes in vitro. Clin Exp Rheumatol 1987; 5: 127-34.

56 Hernandez A D, Cremer M A, Townes A S, Stuart J M, Kang A H. The immune response of guinea-pigs to type II collagen: poor cross-reactivity with homologous type II collagen accounts for resistance to collagen-induced arthritis. Immunology 1988; 63: 619-24.

57 Wooley P H, Chapedelaine J M. Immunogenetics of collageninduced arthritis. CRC Crit Rev Immunol 1987; 8: 1-22.

58 Holmdahl R, Rubin K, Klareskog L, Larsson E, Wigzell H. Characterisation of the antibody response in mice with type II collagen-induced arthritis, using monoclonal anti-type II collagen antibodies. Arthritis Rheum 1986; 29: 400-10.

59 Iribe H, Kabashima H, Ishii Y, Koga T. Epitope specificity of antibody response against human type II collagen in the mouse susceptible to collagen-induced arthritis and patients with rheumatoid arthritis. Clin Exp Immunol 1988; 73: 443-8.

60 Clague R B, Moore L J. IgG and IgM antibody to native type II collagen in rheumatoid arthritis serum and synovial fluid. Arthritis Rheum 1984; 27: 1370-7.

61 Thompson H S G, Henderson B, Spencer J M, Hobbs S M, Peppard J V, Staines N A. Tolerogenic activity of polymerised type II collagen in preventing collagen-induced arthritis in rats. Clin Exp Immunol 1988; 72: 20-5.

62 Arita C, Kaibara N, Jingushi S, Takagisli K, Hotokebuchi T, Arai $K$. Suppression of collagen arthritis in rats by Arter heterologous anti-idiotypic antisera against anticollagen

63 Iribe H, Kabashima H, Kakimoto K, Koga T. Induction of an anti-human type II collagen response by monoclonal antiidiotypic antibody. $\mathcal{F}$ Immunol 1988; 140: 4151-6. 